\title{
PENGARUH PENAMBAHAN JENIS TEPUNG DAUN LEGUMINOSA YANG BERBEDA TERHADAP KONSUMSI, PERTAMBAHAN BOBOT BADAN DAN KONVERSI RANSUM AYAM BROILER
}

\author{
Sulasmi, Yusri Sapsuha, Emy Saelan \\ Staf Pengajar Faperta UNKHAIR-Ternate, e-mail: kisman@gmail.com
}

\begin{abstract}
ABSTRAK
Tujuan dari penelitian ini adalah untuk mengetahui pengaruh penambahan beberapa tepung daun leguminosa diantaranya kelor (Moringa oleifera), lamtoro (Leuchaena leucocephala), dan gamal (Gliricidia sepium) terhadap konsumsi, pertambahan bobot badan dan konversi ransum ayam broiler. Ayam yang digunakan adalah Day Old Chick (DOC) tipe pedaging sebanyak 80 ekor strain CP 707. Penelitian menggunakan metode experimental dengan Rancangan Acak Lengkap (RAL). Terdapat 4 jenis perlakuan ransum $\left(\boldsymbol{R}_{0}=\right.$ ransum kontrol, $R_{1}=$ ransum $+5 \%$ tepung daun lamtoro, $R_{2}=$ ransum $+5 \%$ tepung daun kelor dan $R_{3}=$ ransum $+5 \%$ tepung daun gamal) dengan 4 ulangan. Apabila terdapat perbedaan pengaruh diantara perlakuan maka dilanjutkan dengan Uji Beda Nyata Terkecil (BNT) pada taraf 5\%. Ransum dan air minum diberikan secara ad libitum. Parameter yang diamati pada penelitian ini adalah konsumsi, pertambahan bobot badan dan konversi ransum ayam broiler. Hasil penelitian menunjukkan bahwa penambahan $5 \%$ tepung daun kelor $\left(R_{2}\right)$ dalam ransum memberikan pengaruh yang nyata terhadap pertambahan bobot badan dan konversi ransum ayam broiler dibandingkan penambahan 5\% tepung daun lamtoro $\left(R_{1}\right)$ dan gamal $\left(R_{3}\right)$. Berdasarkan hasil penelitian, disarankan agar dilakukan penelitian lebih lanjut tentang pengaruh penambahan tepung daun kelor (Moringa oleifera) terhadap konsumsi dengan penambahan lebih dari 5\% dalam ransum ayam broiler.
\end{abstract}

Kata Kunci: Ayam Broiler, tepung daun, pertambahan bobot badan, konversi ransum

\section{PENDAHULUAN}

\subsection{Latar Belakang}

Seiring dengan kenaikan jumlah penduduk, pengetahuan gizi yang bertambah serta kemampuan daya beli masyarakat yang meningkat berdampak langsung terhadap pemenuhan protein hewani. Daging ayam broiler sebagai salah satu sumber protein hewani menjadi pangan yang banyak diminati masyarakat. Daging ayam broiler memiliki tekstur yang empuk dan harganya relatif terjangkau dibandingkan ternak penghasil daging lainnya.

Usaha peternakan ayam broiler merupakan jenis usaha pemeliharaan ternak yang unggul karena waktu yang diperlukan relatif singkat. Namun dalam pemeliharaannya memerlukan biaya yang cukup tinggi khususnya pada penyediaan ransum. Ransum merupakan komponen terbesar dari biaya produksi yang dapat mencapai $60 \%$ dari total biaya produksi. Penyediaan ransum yang memadai secara kuantitas dan kualitas sangat diharapkan dalam peningkatan produktifitas ayam broiler. Produktifitas yang baik memerlukan ransum yang tepat, berimbang dan efisien.

Bahan dasar ransum unggas pada dasarnya bersaing dengan kebutuhan manusia. Hal tersebut mengakibatkan harga ransum 


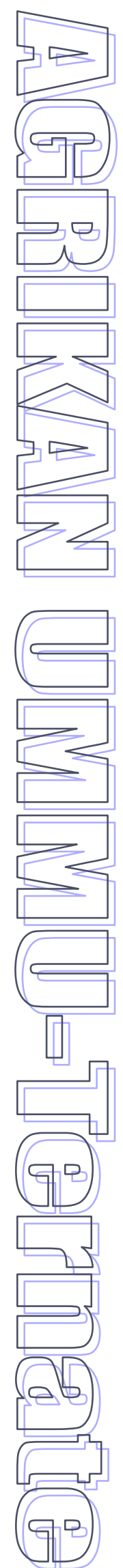

meningkat dan menjadi kendala bagi perternakan rakyat yang baru berkembang. Salah satu upaya untuk mengatasi kendala tersebut adalah dengan memanfaatkan bahan ransum non konvensional yang mudah ditemukan di sekitar wilayah peternakan. Daun lamtoro (Leucaena leucocephala), kelor (Moringa oleifera) dan gamal (Gliricidia sepium) merupakan jenis daun dari tanaman leguminosa yang bayak ditemukan di Maluku Utara (Dinas Pertanian Maluku Utara, 2006).

Leguminosa termasuk jenis tanaman pohon dan perdu yang tidak dapat dijangkau ternak. Pemanfaatan tanaman leguminosa sebagai bahan ransum unggas membutuhkan bantuan manusia. Daun-daun dari jenis tanaman ini dapat diolah menjadi tepung daun sehingga dapat dikonsumsi oleh ayam broiler. Meskipun penambahan tepung daun dibatasi dalam formulasi ransum tetapi diharapkan dapat meningkatkan efesiensi biaya produksi.

Hasil analisa gizi khususnya kandungan protein kasar tepung daun lamtoro (Leucaena leucocephala), kelor (Moringa oleifera) dan gamal (Gliricidia sepium) berturut-turut adalah 9,05\%, 13,05\% dan 11,03\% (Sapsuha dan Sjafani, 2007). Berdasarkan potensi gizi tersebut maka secara kuantitatif tepung daun lamtoro (Leucaena leucocephala), kelor (Moringa oleifera) dan gamal (Gliricidia sepium) dapat dijadikan sebagai bahan ransum ayam broiler. Akan tetapi pengaruh penambahan dari ketiga jenis tepung daun tersebut terhadap konsumsi, pertambahan bobot badan dan konversi ransum ayam broiler perlu dikaji lebih lanjut berdasarkan penelitian ilmiah.

\subsection{Tujuan dan Manfaat Penelitian}

Tujuan dari penelitian ini adalah untuk mengetahui pengaruh penambahan tepung daun lamtoro (Leucaena leucocephala), kelor (Moringa oleifera) dan gamal (Gliricidia sepium) terhadap konsumsi, pertambahan bobot badan dan konversi ransum ayam broiler.

Hasil penelitian diharapkan dapat memberikan informasi ilmiah tentang pengaruh penambahan tepung daun lamtoro (Leucaena leucocephala), kelor (Moringa oleifera) dan gamal (Gliricidia sepium) terhadap konsumsi, pertambahan bobot badan dan konversi ransum ayam broiler. Selain itu diharapkan pemanfaatan tepung daun leguminosa dapat menekan biaya produksi akibat mahalnya harga ransum.

\section{METODE PENELITIAN}

2.1. Tempat dan Waktu Penelitian

Penelitian ini berlangsung pada bulan Mei sampai Juli 2012. Penelitian dilaksanakan dalam dua tahap. Tahapan pertama yaitu pembuatan tepung daun dilaksanakan di Laboratorium Program Studi Peternakan, sedangkan pemeliharaan ayam di Kandang Percobaan Program Studi Peternakan Fakultas Pertanian Universitas Khairun Ternate.

\subsection{Bahan dan Alat}

\subsubsection{Bahan}

Bahan-bahan yang digunakan dalam penelitian ini adalah ayam broiler final stock CP-707 berumur sehari (DOC) yang tidak dibedakan jenis kelaminnya (unsex) sebanyak 80 ekor. Ransum yang digunakan dalam penelitian ini adalah ransum komersial masa awal (starter) dan masa akhir (finisher) dalam bentuk butiran serta tepung daun lamtoro, kelor dan gamal. Kandungan nutrisi ransum komersial yang digunakan dalam penelitian ini dapat dilihat pada Tabel 1.

Tabel 1. Kandungan nutrisi ransum masa starter dan finisher

\begin{tabular}{lcc}
\hline \multirow{2}{*}{ Nutrisi } & Masa Starter & Masa Finisher \\
\cline { 2 - 4 } & & $\%$ \\
Protein & 21,0 & 19,0 \\
Lemak & 5,0 & 5,0 \\
Serat & 5,0 & 5,0 \\
Kadar Air & 13,0 & 13,0 \\
Abu & 7,0 & 7,0 \\
Kalsium & 0,9 & 0,9 \\
Fosfor & 0,6 & 0,6 \\
\hline Sumber: & Data Analisis Proksimat diperoleh dari Label Ransum Ayam Broiler PT. Charoen \\
& &
\end{tabular}




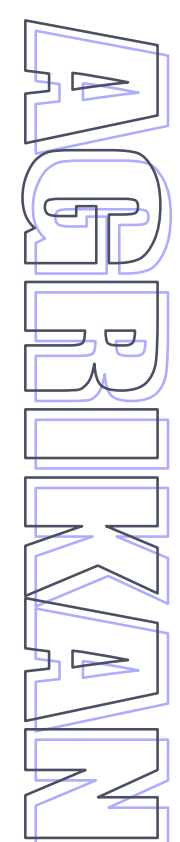

\subsubsection{Alat}

Alat-alat yang digunakan dalam penelitian antara lain kandang baterai sistem postal (litter), tempat ransum dan tempat air minum, lampu lampu pijar 25 watt, timbangan kapasitas $5 \mathrm{~kg}$, pisau, oven dan blender, alat tulis menulis (Spidol boardmarker, buku dan pena), alat-alat kebersihan seperti sapu, lap, ember dan semprotan dan kamera digital.

\subsection{Perancangan Penelitian}

\subsubsection{Perancangan Penelitian}

Rancangan yang digunakan dalam penelitian ini adalah Rancangan Acak Lengkap (RAL). Perlakuan dilakukan sebanyak 4 kali dengan pengulangan sebanyak 4 kali sehingga terdapat 16 unit percobaan. Setiap unit percobaan (tiap kandang) diisi 5 ekor ayam. Setiap perlakuan dalam penelitian dirancang dengan rancangan sebagai berikut :

Kontrol $\left(R_{0}\right) \quad$ : 100\% ransum komersial

Perlakuan $1\left(R_{1}\right)$ : 95\% ransum komersial + 5\% tepung daun lamtoro

Perlakuan $2\left(R_{2}\right)$ : 95\% ransum komersial + 5\% tepung daun kelor

Perlakuan $3\left(R_{3}\right)$ : 95\% ransum komersial + 5\% tepung daun gamal

\subsection{Analisis Data}

Data yang diperoleh dianalisis dengan analisis ragam berdasarkan rancangan acak lengkap (RAL) dengan model matematika sebagai berikut (Hanafiah, 2004) :

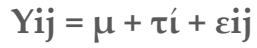

Keterangan :

$Y_{i j}=$ Hasil pengamatan dari perubah pada penggunaan Tepung Daun leguminosa ke-i dengan ulangan ke-j

$\mu=$ Rata-rata pengamatan

$\tau i ́=$ Pengaruh perlakuan $\mathrm{i}$

$\varepsilon i j=$ Pengaruh galat percobaan dari perlakuan ke-i dan ulangan ke-j

dimana :

$$
\begin{aligned}
& i=1,2,3 \text { dan } 4 \\
& j=1,2,3 \text { dan } 4
\end{aligned}
$$

Apabila terdapat perbedaan antar perlakuan dari data yang dianalis maka diuji lanjut dengan Uji Beda Nyata Terkecil (BNT) taraf 5\% (Gomez \& Gomez, 1995).

\subsection{Pengamatan Parameter/Peubah}

Parameter yang diukur dalam penelitian ini adalah :

\subsubsection{Konsumsi Ransum}

Konsumsi ransum dihitung dengan menimbang ransum yang diberikan dan sisa ransum setiap minggu. Konsumsi ransum per ekor perminggu dihitung dengan rumus sebagai berikut :

$\operatorname{Konsumsi~pakan~}(\mathrm{g} / \mathrm{e} / \mathrm{mg})=\frac{\text { Ransum yang diberikan }(g)-\operatorname{Ransum~sisa~}(\mathrm{g})}{\operatorname{Jumlah} \operatorname{Ayam}(\boldsymbol{\theta})}$

\subsubsection{Pertambahan Bobot Badan}

Pertambahan bobot badan setiap minggu diukur dengan menimbang ayam pada akhir minggu. Pertambahan bobot badan per ekor perminggu dihitung dengan rumus sebagai berikut :

$$
P B B=\frac{B B t-(B B t-1)}{\text { Jumlah Ayam }}
$$

Keterangan :

$$
\begin{aligned}
& \text { PBB = Pertambahan bobot badan } \\
& \text { BBt } \\
& \text { BBt-1 }
\end{aligned}
$$

\subsubsection{Konversi Ransum}

Perhitungan konversi ransum dihitung dengan rumus adalah sebagai berikut :

Konversi ransum $=\frac{\text { Konsumsi ransum }(\mathrm{g} / \mathrm{e} / \mathrm{mg})}{\text { Pertambahan bobot badan }(\mathrm{g} / \mathrm{e} / \mathrm{mg})}$

\section{HASIL DAN PEMBAHASAN}

\subsection{Konsumsi Ransum}

Rataan konsumsi ransum (gram/ekor/minggu) tertinggi diperoleh dari $\mathbf{R}_{0}$ $(397,57)$ kemudian diikuti berturut-turut perlakuan $R_{2}(396,11), R_{1}(394,56)$ dan $R_{3}(389,73)$. Analisis sidik ragam menunjukkan bahwa perlakuan berpengaruh sangat nyata terhadap konsumsi ransum ayam broiler $(P>0,01)$. Perbedaan antara perlakuan diuji dengan uji beda nyata terkecil taraf $5 \%$, yang disajikan pada Tabel 2. 
Tabel 2. Data konsumsi ransum ayam broiler setelah pemeliharaan 4 minggu

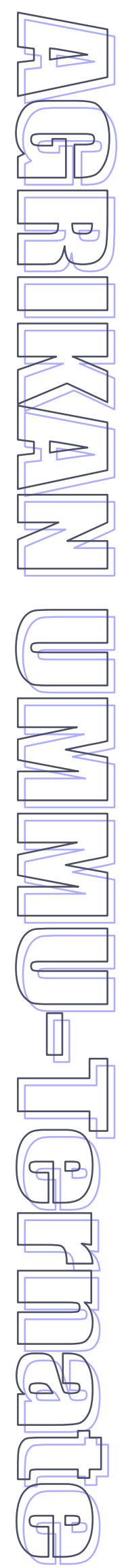

\begin{tabular}{lc}
\multicolumn{1}{c}{ Perlakuan } & $\begin{array}{c}\text { Rata-rata konsumsi ransum } \\
\text { (gram/ekor/minggu) }\end{array}$ \\
\hline $\mathrm{R}_{0}$ (ransum kontrol) & $397,57^{\mathrm{b}}$ \\
$\mathrm{R}_{1}$ (penambahan 5\% tepung daun lamtoro) & $394,56 \mathrm{~b}$ \\
$\mathrm{R}_{2}$ (penambahan 5\% tepung daun kelor) & $396,11 \mathrm{~b}$ \\
$\mathrm{R}_{3}$ (penambahan 5\% tepung daun gamal) & $389,73 \mathrm{a}$ \\
\hline Keterangan : huruf yang berbeda (a, b) pada kolom yang sama menunjukkan perbedaan yang nyata (P>0,05)
\end{tabular}

Keterangan : huruf yang berbeda $\left({ }^{a, b}\right)$ pada kolom yang sama menunjukkan perbedaan yang nyata $(P>0,05)$

Hasil uji BNT menunjukkan bahwa konsumsi ransum $R_{0}$ (kontrol) tidak berbeda nyata dengan perlakuan $R_{1}$ (penambahan $5 \%$ tepung daun lamtoro) dan $R_{2}$ (penambahan $5 \%$ tepung daun kelor). Sedangkan $R_{0}$ (ransum kontrol), perlakuan $R_{1}$ (penambahan $5 \%$ tepung daun lamtoro) dan $R_{2}$ (penambahan $5 \%$ tepung daun kelor) jika dibandingkan dengan perlakuan $R_{3}$ (penambahan $5 \%$ tepung daun gamal) menunjukkan perbedaan yang nyata $(P>0,05)$. Hal ini menunjukkan bahwa penambahan $5 \%$ tepung daun gamal dalam ransum dapat menurunkan konsumsi ayam broiler.

Hasil penelitian menunjukkan bahwa $R_{0}$ (ransum kontrol) lebih banyak dikonsumsi oleh ayam broiler. Hal ini diduga karena pengaruh warna dari ransum yang diberikan. Sebagaimana pendapat Chruch (1979) cit Syah (2007) yang menyatakan bahwa palatabilitas dipengaruhi oleh bentuk, bau, rasa, tekstur, dan suhu makanan yang diberikan. Ransum kontrol $\left(R_{0}\right)$ memiliki warna mencolok yaitu kuning agak kecoklat-coklatan. Sifat warna tersebut merangsang perhatian ayam broiler sehingga secara kuantitas lebih banyak dikonsumsi. Hasil penelitian Retnani., et al (2009) bahwa ayam broiler lebih menyukai ransum $R_{0}$ (kontrol) atau ransum tanpa perlakuan. Hal ini didukung oleh Gunther dan Jones (1962) cit., Ahmad (1988) bahwa ayam lebih menyenangi warna daerah oranye kuning dengan sifat warna yang mengkilap dan merangsang perhatian.

Rendahnya konsumsi ransum $R_{3}$ dalam penelitian ini ditunjukkan dengan rataan 389,73 gram/ekor/minggu. Hal ini diasumsikan bahwa tingkat palatabilitas ayam broiler terhadap penambahan $5 \%$ tepung daun gamal cenderung menurun. Penambahan 5\% tepung daun gamal menyebabkan bau dari ransum yang diberikan lebih menyengat daripada perlakuan ransum yang lain $R_{0}$ (ransum kontrol) $R_{1}$ (penambahan $5 \%$ tepung daun lamtoro) dan $\mathrm{R}_{2}$ (penambahan $5 \%$ tepung daun kelor).

Coumarin merupakan zat anti nutrisi turunan dari glukosida dengan bau yang menyengat dan rasa yang pahit (Widodo, 2005). Hal tersebut sesuai dengan pendapat Mathius., et al (1981) cit., Lestian (2007) yang menyatakan bahwa bau coumarin yang terkandung dalam tepung daun gamal akan mengurangi tingkat palatabilitas ayam broiler. Hal ini didukung oleh pendapat Sutikno dan Supriyadi (1985) bahwa daun gamal memiliki palatabilitas rendah dikarenakan baunya yang spesifik. Bau yang spesifik ini berasal dari senyawa coumarin, sehingga untuk mengatasi hal tersebut dapat dilakukan dengan pelayuan daun gamal sebelum diberikan pada ternak.

Ahmad (1986) cit., Agustina (2009) menyatakan bahwa konsumsi tepung daun gamal adalah $0,17 \%$ dari total ransum yang diberikan secara kafetaria terhadap ayam broiler. Hasil yang ditunjukkan jauh lebih rendah daripada konsumsi tepung daun lamtoro yaitu $0,18 \%$ serta tepung daun singkong yang mencapai $0,20 \%$. Dinyatakan bahwa rendahnya konsumsi tepung daun gamal akibat bau coumarin yang menyengat. Ransum yang ditambahkan dengan tepung daun gamal mengakibatkan bau ransum menyengat dan menambah rasa pahit dalam ransum (Rahardjo, 2004).

\subsection{Pertambahan Bobot Badan}

Rataan pertambahan bobot badan ayam broiler (gram/ekor/minggu) tertinggi diperoleh dari perlakuan $R_{2}(282,24)$ kemudian diikuti berturut-turut $R_{0}(249,74), R_{1}(246,40)$ dan $R_{3}$ $(237,03)$. Analisis sidik ragam menunjukkan bahwa perlakuan berpengaruh sangat nyata $(P>0,01)$ terhadap pertambahan bobot badan ayam broiler. Perbedaan antara perlakuan diuji 
dengan uji beda nyata terkecil taraf $5 \%$, yang disajikan pada Tabel 3.

Hasil uji BNT menunjukkan bahwa pertambahan bobot badan terbaik terdapat pada perlakuan $R_{2}$ (penambahan $5 \%$ tepung daun kelor) dengan rataan 282,24 (gram/ekor/minggu) dan berpengaruh nyata
$(P>0,05)$ terhadap $R_{0}$ (ransum kontrol) yaitu 249,74 (gram/ekor/minggu) perlakuan $R_{1}$ (penambahan $5 \%$ tepung daun lamtoro) dengan rataan 246,40 gram/ekor/minggu dan $R_{3}$ (penambahan $5 \%$ tepung daun gamal) dengan rata-rata pertambahan bobot badan 237,03 (gram/ekor/minggu).

Tabel 2. Data pertambahan bobot badan ayam broiler setelah pemeliharaan 4 minggu

\begin{tabular}{lc}
\hline \multicolumn{1}{c}{ Perlakuan } & Rata-rata PBB (gram/ekor/minggu) \\
\hline $\mathrm{R}_{0}$ (ransum kontrol) & $249,74^{\mathrm{a}}$ \\
$\mathrm{R}_{1}$ (penambahan 5\% tepung daun lamtoro) & $246,40^{\mathrm{a}}$ \\
$\mathrm{R}_{2}$ (penambahan 5\% tepung daun kelor) & $282,24^{\mathrm{b}}$ \\
$\mathrm{R}_{3}$ (penambahan 5\% tepung daun gamal) & $237,03^{\mathrm{a}}$ \\
\hline
\end{tabular}

Keterangan : huruf yang berbeda $(a, b)$ pada kolom yang sama menunjukkan perbedaan yang nyata $(P>0,05)$

Hasil penelitian menunjukkan bahwa perlakuan dengan penambahan $5 \%$ tepung daun kelor dapat meningkatkan pertambahan bobot badan ayam broiler $(282,24$ gram/ekor/minggu). Peningkatan tersebut diduga karena kandungan protein kasar tepung daun kelor lebih tinggi daripada tepung daun lamtoro dan gamal. Persentase protein kasar tepung daun kelor adalah $13,05 \%$, tepung daun gamal $11,03 \%$ sedangkan tepung daun lamtoro adalah 9,05\% (Sapsuha dan Sjafani, 2007). Asumsi tersebut dipertegas oleh pendapat Wahyu (1992) bahwa protein dibutuhkan oleh ayam broiler untuk memenuhi tiga macam kebutuhan yaitu untuk pertumbuhan jaringan, hidup pokok dan pertumbuhan bulu. Hal ini didukung pula oleh pendapat Rasyaf (1992) yang menyatakan kebutuhan protein berperan penting pada pertumbuhan ayam broiler selama masa pertumbuhan.

Penambahan $5 \%$ tepung daun gamal $\left(R_{3}\right)$ dalam ransum mengakibatkan terjadinya penurunan pertambahan bobot badan ayam broiler. Hal ini sesuai dengan konsumsi pada perlakun $R_{3}$ yang lebih rendah dengan rataan 389,73 gram/ekor/minggu dibandingkan $R_{0}$ (ransum kontrol), $\mathrm{R}_{1}$ (penambahan $5 \%$ tepung daun lamtoro) dan $R_{2}$ (penambahan $5 \%$ tepung daun kelor). Asumsi lain bahwa penurunan pertambahan bobot badan ayam broiler dipengaruhi oleh kandungan serat kasar dalam ransum. Sebagaimana dijelaskan Wahyu (1992) bahwa penambahan tepung daun gamal akan meningkatkan kandungan serat kasar dalam ransum, sehingga ternak menjadi cepat kenyang. Selanjutnya ditambahkan serat kasar yang tinggi akan mempengaruhi daya cerna, karena energi untuk pertumbuhan semakin berkurang. Pendapat tersebut sesuai dengan Siregar et al., (1980) bahwa semakin rendah daya cerna ransum akan mengakibatkan penurunan penggunaan energi untuk pertumbuhan ayam broiler.

Trisnatari (2007) yang menyatakan bahwa tepung daun gamal mempunyai kandungan serat kasar yang tinggi $(20,70 \%)$ dibandingkan tepung daun lamtoro dan gamal. Hal ini menyebabkan tingkat kecernaan protein terhadap ransum cenderung menurun. Pendapat tersebut diperkuat oleh Farrel (1978) yang menyatakan bahwa bahan ransum yang mengandung zat yang sulit atau tidak bisa dicerna seperti serat kasar yang tinggi akan menyebabkan tingkat kecernaan protein yang rendah.

Asumsi lain yang dapat mempengaruhi penurunan pertambahan bobot badan ayam broiler dalam penelitian ini adalah zat anti nutrisi yang terkandung dalam tepung daun gamal. Sebagaimana pendapat Smith and Van Houtert (2000) bahwa tepung daun gamal sebagai bahan ransum ternak mengandung zat anti nutrisi yaitu coumarin. Selanjutnya dijelaskan bahwa senyawa coumarin dapat menurunkan pertambahan bobot badan ayam broiler karena adanya penguraian coumarin menjadi dicoumerol. Dicoumerol diperkirakan merupakan hasil konversi dari coumarin yang disebabkan oleh bakteri ketika terjadi fermentasi atau pemanasan (Widodo, 2004). 
Selanjutnya dicoumerol dapat mengikat vitamin $\mathrm{K}$ dan bersifat menganggu (antagonis) serta menggumpalkan darah.

Raharjo (2004), menyatakan bahwa rataan pertambahan bobot badan ayam broiler yang diberi penambahan tepung daun gamal berkisar antara 283,04 gram/ekor/minggu. Hasil yang ditunjukkan relatif hampir sama dengan rataan pertambahan bobot badan pada penelitian ini dengan kisaran rataan 253,85 gram/ekor/minggu.

\subsection{Konversi Ransum}

Rataan konversi ransum ayam broiler terbaik 1,40 diperoleh dari perlakuan $R_{2}$ (penambahan 5\% tepung daun kelor) kemudian diikuti berturut-turut $\mathbf{R}_{0}$ (ransum kontrol), $\mathbf{R}_{1}$ (penambahan 5\% tepung daun lamtoro) dan $R_{3}$ (penambahan $5 \%$ tepung daun gamal) masingmasing dengan rataan 1,$58 ; 1,62$ dan 1,65. Analisis sidik ragam menunjukkan bahwa perlakuan berpengaruh sangat nyata $(P>0,01)$ terhadap konversi ransum ayam broiler. Perbedaan antara perlakuan diuji dengan uji beda nyata terkecil taraf $5 \%$, yang disajikan pada Tabel 4.

Hasil uji BNT menunjukkan bahwa perlakuan $R_{2}$ (penambahan $5 \%$ tepung daun kelor) berpengaruh nyata terhadap konversi ransum ayam broiler daripada $\boldsymbol{R}_{0}$ (ransum kontrol), perlakuan $R_{1}$ (penambahan $5 \%$ tepung daun lamtoro) dan $R_{3}$ (penambahan $5 \%$ tepung daun gamal). Sedangkan antara perlakuan $\mathbf{R}_{0}$, $R_{1}$ dan $R_{3}$ menunjukkan pengaruh yang tidak berbeda nyata dengan perlakuan. Rataan konversi $R_{3}$ lebih tinggi dibandingkan perlakuan lainnya dengan nilai 1,65. Hal ini menunjukkan bahwa penambahan $5 \%$ tepung daun gamal dalam ransum dapat menurunkan konversi ayam broiler. Semakin tinggi nilai konversi ransum menunjukkan tidak efisiennya ransum yang digunakan.

Tabel 4. Data konversi ransum ayam broiler setelah pemeliharaan 4 minggu

\begin{tabular}{lc}
\hline \multicolumn{1}{c}{ Perlakuan } & $\begin{array}{c}\text { Rata-rata konversi ransum } \\
\text { (gram/ekor/minggu) }\end{array}$ \\
\hline $\mathrm{R}_{0}$ (ransum kontrol) & $1,58^{\mathrm{a}}$ \\
$\mathrm{R}_{1}$ (penambahan $5 \%$ tepung daun lamtoro) & $1,62^{\mathrm{a}}$ \\
$\mathrm{R}_{2}$ (penambahan $5 \%$ tepung daun kelor) & $1,40^{\mathrm{b}}$ \\
$\mathrm{R}_{3}$ (penambahan $5 \%$ tepung daun gamal) & $1,65^{\mathrm{a}}$ \\
\hline Keterangan : huruf yang berbeda $\left(^{a, b}\right)$ pada kolom yang sama menunjukkan perbedaan yang nyata $(P>0,05)$
\end{tabular}

Hasil penelitian menunjukkan bahwa perlakuan $R_{2}$ memberikan pengaruh terbaik terhadap konversi ransum dengan rataan 1,40 . Hal ini ditunjukkan dengan konsumsi yang rendah namun bobot badan yang dicapai cukup tinggi. Konsumsi pada $R_{2}$ adalah 396,11 gram/ekor/minggu dan dapat memberikan pertambahan bobot badan dengan rataan 282,24 gram/ekor/minggu, lebih tinggi dibandingkan dengan $R_{0}$ (ransum kontrol) perlakuan $R_{1}$ (penambahan $5 \%$ tepung daun lamtoro dan $R_{3}$ (penambahan $5 \%$ tepung daun gamal). Diduga peningkatan konversi ransum pada perlakuan $\mathbf{R}_{2}$ dipengaruhi oleh tingkat kecernaan ayam broiler yang cukup baik terhadap ransum yang diberikan. Hal ini sesuai dengan pendapat Yasin dan Indarsih cit., Sapsuha (2006) bahwa faktor yang mempengaruhi angka konversi ransum adalah kualitas ransum, strain ayam dan tatalaksana pemberian ransum. Pendapat tersebut diperkuat pula oleh Amrullah (2003) bahwa selain kualitas ransum, konversi ransum juga dipengaruhi oleh teknik pemberian ransum. Kemudian dijelaskan teknik pemberian ransum yang baik dapat menekan angka konversi pakan sehingga keuntungan banyak bertambah. Rasyaf (2002) menjelaskan bahwa semakin rendah konversi ransum adalah semakin baik karena konversi ransum yang rendah menunjukan efesiensi penggunaan ransum yang baik.

\section{PENUTUP}

\subsection{Kesimpulan}

Berdasarkan hasil penelitian dapat disimpulkan bahwa penambahan 5\% tepung daun kelor (Moringa oleifera) memberikan pengaruh terbaik terhadap pertambahan bobot badan dan konversi ransum ayam broiler dibandingkan dengan penambahan $5 \%$ tepung 
